To cite this article: Arnau-Sabatés, L., Marzo, M.T., Jariot, M. i Sala-Roca, J. (2013). Learning basic employability competence: a challenge for the active labour insertion of adolescents in residential care in their transition to adulthood. European Journal of Social Work, 17(2), 252-265. doi: 10.1080/13691457.2013.802227

Post-printed version

\title{
Learning basic employability competence: a challenge for the active labour insertion of adolescents in residential care in their transition to adulthood
}

\author{
Arnau-Sabatés, L. ${ }^{a}$, Marzo, M.T. ${ }^{\text {, }}$ Jariot, M. ${ }^{\text {a }}$, and Sala-Roca, J. ${ }^{\text {a }}$ \\ ${ }^{a}$ Universitat Autònoma de Barcelona, Barcelona \\ ${ }^{\mathrm{b}}$ Universitat Ramon Llull, Barcelona
}

\begin{abstract}
The teaching of basic employability competence from a very early age is of preventive value in the young people in residential care transition to adulthood. Research relates employability competence (finding and holding down a job and gaining promotion in the labour market) with positive career outcomes and employment opportunities. In this study, conceptual methods for understanding employability are analyzed and some existing international studies of employability skills are reviewed, although all of these are deemed partial approaches to the needs of children and young people in residential care. Our proposal, the IARS Employability Competence Framework, developed by means of a collaborative and integrated approach with experts, provides a complete picture of how employability competences are important for preparing young people in residential care not only for active labour insertion but also in terms of their comprehensive development. A selection of a cluster of eight employability competences (self-organization, decision making and problem solving, teamwork, communication, perseverance, professional project development, flexibility and responsibility) and their components are presented, as well as its educational implications within children's homes.
\end{abstract}

Key words: young people in residential care, transition to adulthood, employment outcomes, employability competence, active labour insertion 


\section{The transition process of young people in residential care to adulthood: employment outcomes}

Leaving care is one of the most challenging events that young people living in children's homes have to face. It involves transitioning from child-welfare dependence to self-sufficiency (Mendes, 2009). The literature has referred to aging out of care as "instant adulthood" (Green and Powers, 2007) in which young people have to face the transition to adulthood abruptly by dealing with the day-to-day aspects of their lives outside of the care system. These "compressed and accelerated transitions" experienced by care leavers contrasts sharply with the non-foster-care young people whose transition tends to be lengthier and more gradual (Stein, 2006).

There are numerous obstacles and added barriers that young people out of care have to overcome with respect to their peers which make them more vulnerable and disadvantaged (Avery and Freundlich, 2009; Mendes, 2009). The abruptly ending of economic, social, and emotional support coincides with a period that is usually conflictive: the final years of schooling or the start of employment and the physical and psychological changes related to adolescence (Paul-Ward, 2008). Comparisons between countries reveal that the challenges of transitioning are very similar, although the legal development and the responses given by different policies and institutions differ significantly (see various studies undertaken within the 16 countries reviewed in the INTRAC publication by Stein and Munro, 2008; for an international review see López et al., 2012).

Care leavers have been found to experience significant deficits including poor educational outcomes (Farruggia, Greenberger, Chen and Heckhausen, 2006; Tilbury, Buys and Crees, 2009) and several problems related with mental and physical health issues, criminal activity, risky sexual behaviour, homelessness, substance abuse, high rates of unemployment, inadequate social-support systems and teenage parenthood (Cashmore and Paxman, 2007; Davidson, Devaney and Sprott, 2011; Courtney et al., 2005; Courtney and Dworsky, 2006; Dixon, 2006; Massinga and Pecora, 2004). These deficits and problems show that young people in residential care are not sufficiently prepared to find ways of covering their material and psychosocially demanding needs outside the care system (obtaining and maintaining employment, finding accommodation, maintaining good health, continuing education, etc.). International research shows that care leavers have a high risk of social exclusion when going through a vulnerable situation, which affects their possibilities of building life projects (Stein and Munro, 2008).

Employment is a critical dimension of the transition process to adulthood. Although different children's homes will have been working on improving their young people employment rates, there still are a large number of young people not able to find a job 
and the employment outcomes continue to be quite disappointing. A Midwest evaluation of 603 individuals who left foster care a year earlier reported that $92 \%$ had accessed some paid work but only $40 \%$ were currently employed (Courtney and Dworsky, 2006), similar results were found by Naccarato, Brophy and Courtney (2010). A survey of 143 young people in residential care in Catalonia, who left the centre between 2 and 5 years earlier and who had not been diagnosed with mental deficiency, found that $65.7 \%$ of them received work training but only $59.9 \%$ worked. A similar percentage was found in their peers not in residential care even though most of them were still enrolled school (authors' own, 2009b). It is also noted by the research that most care leavers who find a job have great difficulties keeping it. Perhaps they found a job but it was temporary, unqualified and carried out under precarious conditions. At a personal level, their skills for maintaining or changing employment and for managing themselves through lifetime-employment transitions are very underdeveloped. These features have a negative influence, showing high labour mobility and labour instability.

International research also shows that a lack of basic life and work related skills has been linked negatively to young people in care holistic developmental process and their career outcomes (Courtney and Dworsky, 2006; Berridge, 2007; Dixon, 2006, 2007; Pecora et al., 2006) and makes it difficult to normalize their situation in society (for an international review, see Gilligan, 2007). In Catalonia, successful employment outcomes of young people out of residential care were related to emotional regulation, support from collaborative families and employability skills such as autonomy, acceptance of the rules, perseverance at work and an ability to negotiate (authors' own, 2009a). The identification and teaching of basic employability competence (finding and holding down a job and gaining promotion in the labour market) from a very early age is of preventive value in the young people' in care transition to adulthood.

Thus, it is very important to design strategies that contribute to improving active labour insertion, rather than simply having a job. Active labour insertion is understood as keeping people involved and active in the labour-market after fostering, thereby strengthening their qualities and potential to maintain and progress through fulfilling employment that benefits personal and professional development.

The present research attempts to systematically analyze the theoretical framework of employability concept due to developmental research and theory suggest that an essential component of the successful development of children and young people in residential care is learning social and employability skills. Also, we propose an employability competence model (IARS Employability Competence Framework) developed by means of a collaborative and integrated approach with experts. This model provides a complete picture of which employability competence would be important for preparing young people in residential care not only for their active labour insertion but also in terms of their comprehensive development. 


\section{Preparing transition to work: Which practices? Which career development programmes?}

Research shows that there is a growing risk of young people in residential care with respect to their transition process (skill deterioration, poor educational attainments, high rates of unemployment, lower wages and unstable jobs). We know from existing research that some of these poor employment outcomes can be attributed to a range of pre-care, in-care and post-care experiences (Dixon, 2007; Davidson et al., 2011; Mendes, 2009). Young people's career outcomes cannot be analysed separately from their previous experience, nor the experiences undergone in care (Wade and Dixon, 2006). Many children enter in residential care with a deficit of socialization and with previous experiences of abandonment, mistreatment or abuse. Additionally, experiences in-care -the characteristics of children's homes, the preparation they receive for the transition process, the ages at which they leave care and the emotional involvement from social workers (Attar-Schwartz, 2008; Cashmore and Paxman, 2007; Courntey et al., 2005; Dixon 2007; Mendes, 2009) - and the experiences undergone out of care, including a social support network, have an impact on their active labour insertion after coming of age.

Researchers suggest the importance of preparing the transition process by implementing programmes focussing on employability skills (Berridge, 2007; Dixon, 2006, 2007; Mendes, 2009; Tilbury et al., 2009). Most of these employability skills are developed in a family context in later childhood (Sheffield, Silk, Steinberg, Myers and Robinson, 2007.) It is in the family context where children have the opportunity to develop, through informal education, certain social rules and employability skills necessary to build their life projects and to be prepared for employment. Children and young people placed in residential child care environments, in contrast with those in foster care (living with substitute families) may not have such great opportunities; they don't have the family context in which most of these competences could be developed. The educational staff in residential homes therefore has to provide them with the guidance that a child usually receives in a family. They are central in helping them to participate and become involved in their employability competence development.

It would seem to be necessary to improve the conditions and programmes that are successful in preparing for an active labour insertion for unprotected children. There are a wide range of employment-support programmes in the United Kingdom, the United States and Australia, focused on promoting better training and employment outcomes (for an international review, see Mendes, 2009). Most of these programmes include different models of dual vocational training (employment skills and job-readiness courses and work-experience placements) and try to establish more or less effective connections between training, employment and education. Programmes that support 
participants in developing greater habits, attitudes and skills as preparation for employment (not only in looking for work) and designing a viable career plan tend to be more effective in their long-term employment outcomes (Foster Care Work Grup, 2004; Pugh, 2008), even if few external effectiveness evaluations have been conducted in this way (Dutton, 2006).

Unfortunately, most of these programmes are not planned systematically and are applied in the last years when young people have to leave the centre (Dixon, 2007; Mendes, 2009). This lack of anticipation frustrates an adequate skill provision for young people leaving children's care. Researchers point out that, frequently, educational issues for preparing the transition are not given sufficient priority by social workers (Gilligan, 2007). Educators prioritize "work first" interventions for young people lacking skills because of the pressure of being economically independent at the age of 18. But these interventions may only lead to unstable employment, unemployment and to a high risk of social exclusion.

The literature shows the importance of facilitating smoother transitions through appropriate training schemes that increase young people's personal and social development, emphasizing the importance of schooling as a basic foundation of skills (Courtney et al., 2005; Mendes 2009; Stein, 2004). In addition to research, the implementation of certain laws such as the recent Children's Act in Catalonia (Llei dels drets $i$ oportunitats de la infància $i$ adolescència de Catalunya) recommends working in a preventive and progressive way and providing the necessary resources to contribute to enhancing autonomy and self-confidence when young people leave the care system. Education for developing employability competences must be gradual, systematic and planned in order to minimize risks.

\section{Educating basic employability competence: what does employability provide?}

Employability as a multi-levelled and multi-dimensional concept is challenging to define consensually. There are several definitions in the literature but the term is not usually clearly defined. The studied definitions brings three conceptual ways of understanding employability from a more limited to a broader definitions of the concept (for a review, see Forrier and Sels, 2003; Thijssen and Van der Heijden, 2003; Thijssen, Van der Heijden, and Rocco, 2008).

The most limited definitions and also the most current component in employability descriptions are concerned with personal adequacy to performing a job. One of the most 
popular and widely accepted definitions of employability is the capability to move selfsufficiently within the labour market to realise one's potential thought sustainable employment (Hillage and Pollard, 1998). In accordance with this definition, employability is related with gaining and retaining fulfilling work. Other definitions overlay this core notion even when they emphasise other aspects such as employability.

Most authors perceive this first conceptualization as too limiting because it establishes no place for individual capabilities. For this reason, certain personal competences have been included in the definition termed 'employability competences' or 'employability skills' (Fugate, Kinicki and Ashforth, 2004; McArdle, Waters, Briscoe and Hall, 2007; Thijssen and Van der Heijden, 2003; Thijssen et al. 2008; Kirschner and Thijssen, 2005; Van der Heijde and Van der Heijden, 2006). In this sense, employability can be understood as the possession of basic skills or attributes that employers and the labour market specifies; however, in this second approach, the contextual differences are not yet taken into consideration.

The broadest definitions of the concept also takes into consideration contextual conditions and includes context-related factors such as the labour-market's financial situation or the discrimination of certain groups in the labour market that influence (by promoting or inhibiting) individual employability. The definitions that follow this third conceptualization show that employability is a dynamic characteristic that depends on personal factors (life circumstances, individual attributes, willingness, resilience) and labour market context (Forrier and Sells, 2003; Lindsay, McQuaid and Dutton, 2007; McQuaid, 2006; Yorke and Knight, 2006). This is referred to as a holistic view of employability.

In our opinion, employability is essential for enhancing young people in residential care human and social capital development. Whereas contextual characteristics are important for determining chances of gaining and maintaining a job, context is not an essential part of employability. We therefore prefer the second conceptualization of employability.

Regarding problems that young people placed in residential care may have, we are attracted to the definition by Fugate et al (2004) in which employability means being equipped for a job, in discordance with the limited definitions of employability that prioritise job acquisition over preparedness for life-long employment. The preparation for lifetime employability (not only for entry-level employment) at a very early age could provide an effective bridge to stable employment, especially for low- skilled young people in residential care, and may increase their career chances whatever the kinds of work or the given labour market characteristics. 


\section{The 'big eight' competences of employability}

Certain models of competence have been developed in the research, indicating the main definitions of concept and competence types (Kirschnher and Thijssen, 2005; Le Boterf, 2001; Mertens, 1998).

Employability competence refers to those basic competences required to acquire and maintain a job, independently of employment type. They are integrated, developmental and transferable to other personal and professional situations or roles that the person encounters (Kearns, 2001). We will refer to employability competence instead of employability skills to include not only many specific work-related abilities but also a variety of attitudes, habits and personal attributes that have been learned and accumulated throughout life. Competences are more than simply knowledge that has been taught; they involve a mobilization of practical skills, creative abilities and other psychosocial resources such as attitudes, motivation and values (Descy and Tessaring, 2002; DeSeCo, 2003).

The Secretary's Commission on Attaining Necessary Skills (SCANS) of the United States Department of Labor defines employability skills as those skills necessary to improve the employee internal potential for primary entry-level employment. They validate the necessary skills that society must provide to every child by the age of 16 and distinguish five employability areas: basic skills (reading, writing, mathematics, speaking and listening), interpersonal skills (social, negotiation, leadership, teamwork and cultural diversity), personal qualities (self-esteem, self-management and responsibility) and thinking skills (creative thinking, problem-solving, decision-making and visualization) (U.S. Department of Labour, SCANS, 1992). This work has been used as a starting point for other international studies and research. However, SCANS has been contested by different authors because these skills are related to entry-level employment but do not include those competences necessary to maintaining a job and to promotion in the workplace, nor does it include those competences needed at all stages of the personal and professional career (Packer, 2000).

Some governmental institutions from the economic and educational sector have tried to provide a list of employability skills that will actually enable an individual to acquire and retain a job. The labour market approach is represented by ACCI and BCA (2002), Australian Government (2006) and UKCES (2009, 2011). DeSeCo (Definition and Selection of Competencies) project (2003)—which includes basic everyday life competence-, European Civil Society (2004) and other OCDE projects and researchers (e.g. Descy and Tessaring, 2002, researchers of the European Tuning Project; Down, 2000; Kearns, 2001) presents an agreed new profile of understanding employability competence using an educational and social discourse instead of the attributes desired by employers. In accordance with this idea, employability competence prepares for 
employment and for life and is blended with personal and professional development and with a life-long learning approach. In our opinion, there are few proposals of basicemployability competences that could be totally adapted to young people in residential care.

These existing studies of competence are highlighted for their important contribution in identifying the basic employability competence; among them there is broad agreement in certain competence areas such as problem solving, self-management, teamwork and communication. However, this review leads us to point out the need for a general framework regarding young people in residential care. The majority of studies analysed are uncompleted and do not explicitly list important competence that are crucial for young people' development process. Young people in residential care need to develop a wide range of basic competences in their everyday lives in order to face complex challenges in various contexts, including employment demands.

The IARS conceptual framework relates to individual's basic employability competence and identifies eight clusters of basic competence (those that are essential to gaining and maintaining employment and to promotion in the workplace). These broad competences are interrelated and are the basis for identifying and mapping competence components. We have selected these 8 basic competences by focusing on the competence aspects that are trainable and are important not only for employers but also for young people in residential care, through helping them to respond to important demands in the labour context and to the demands of modern life (justified in the 'Why?' column).

To defend this set of competences, we have developed a collaborative and integrated approach with experts from different disciplines who have informed and validated a selection of the most important and desirable employability competences for successful employment and career outcomes for young people in residential care.

The content validation process was conducted by a panel of six experts experienced in the subject matter from the social sciences field (Education and Psychology). The assessment process included an initial evaluation session and two focus group sessions. The first session consisted of proposing which competences young people in residential care need in order to gain and maintain employment and to obtain promotion in the labour market. During the developmental phase (in the next two sessions) experts validate and refine the content and organization of the employability competences previously identified. Results of summative expert panel review provide evidence of alignment of board competence and competence elements with employability standards, content validity, and appropriateness with intended use.

The broad competences and competence components are shown below: 
Table 1. The IARS Employability Competence Framework

\begin{tabular}{|c|c|c|}
\hline Description of board competence & Why? & Description of competence components \\
\hline \multirow{4}{*}{$\begin{array}{l}\text { SELF-ORGANIZATION } \\
\text { Preparing, managing and developing } \\
\text { a task/work taking into account the } \\
\text { aims and every detail. }\end{array}$} & \multirow{4}{*}{$\begin{array}{l}\text { This is important because it prepares } \\
\text { for acting autonomously and } \\
\text { translating work demands and } \\
\text { personal goals into acts, taking into } \\
\text { account the time and resources } \\
\text { available. }\end{array}$} & Planning aims \\
\hline & & $\begin{array}{l}\text { Managing one's own time and other resources to } \\
\text { carrying out tasks more efficiently }\end{array}$ \\
\hline & & $\begin{array}{l}\text { Developing a proactive strategy to developing tasks } \\
\text { efficiently }\end{array}$ \\
\hline & & Being methodical at doing tasks \\
\hline \multirow{6}{*}{$\begin{array}{l}\text { EDUCATIONAL-PROFESSIONAL } \\
\text { PROJECT CONSTRUCTION } \\
\text { Identifying and analysing by oneself } \\
\text { the training and work experience } \\
\text { needed to obtain the desirable job, } \\
\text { maintain it and gain promotion in } \\
\text { the labour market, acting } \\
\text { proactively. }\end{array}$} & \multirow{6}{*}{$\begin{array}{l}\text { It reflects the need for orientation } \\
\text { towards the future by realizing one's } \\
\text { identity and career goals (academic } \\
\text { and employment). Conducting life, } \\
\text { work plans and personal projects to } \\
\text { develop one 's self. It requires an } \\
\text { awareness of one's work and life } \\
\text { environment. Implies decision, choice } \\
\text { and action-taking in a responsible way. }\end{array}$} & Defining and prioritising professional goals \\
\hline & & $\begin{array}{l}\text { Having Knowledge about the profession and the } \\
\text { changes that will take place in work requirements, } \\
\text { professional training...etc. }\end{array}$ \\
\hline & & Evaluating personal learning capacities and needs \\
\hline & & $\begin{array}{l}\text { Having confidence in personal capacities for } \\
\text { learning }\end{array}$ \\
\hline & & Initiating life-long learning activities \\
\hline & & Taking initiative when required \\
\hline \multirow{6}{*}{$\begin{array}{l}\text { DECISIONS MAKING AND PROBLEM } \\
\text { SOLVING } \\
\text { Being able to take decisions, identify } \\
\text { problems, and resolve them in an } \\
\text { effective and constructive way, } \\
\text { taking into consideration different } \\
\text { options and its viability. }\end{array}$} & \multirow{6}{*}{$\begin{array}{l}\text { Conflict is consubstantial and occurs in } \\
\text { all aspects of life, especially in work. It } \\
\text { is an essential tool to making choices } \\
\text { and to taking an active part in } \\
\text { managing and resolving work conflicts, } \\
\text { with an effective management of } \\
\text { emotions. Requires consideration of } \\
\text { the interest of other team workers. }\end{array}$} & Identifying relevant problems \\
\hline & & $\begin{array}{l}\text { Knowing the goals that you want to reach in order } \\
\text { to resolve problems; controlling emotions }\end{array}$ \\
\hline & & Collecting, analysing and organizing information \\
\hline & & $\begin{array}{l}\text { Identifying a range of options and analysing areas } \\
\text { of agreement and disagreement }\end{array}$ \\
\hline & & $\begin{array}{l}\text { Choosing and executing the best option and testing } \\
\text { assumptions }\end{array}$ \\
\hline & & Expressing decisions concerning others \\
\hline \multirow{5}{*}{$\begin{array}{l}\text { TEAMWORK } \\
\text { Having a good relationship with } \\
\text { others to reach team goals }\end{array}$} & \multirow{5}{*}{$\begin{array}{l}\text { It is necessary to learn, live and work } \\
\text { with others. Implies co-operation. } \\
\text { Allows individual to initiate, maintain } \\
\text { and manage personal relationship in } \\
\text { the work context, emphasizing } \\
\text { emotional intelligence (e.g., empathy). }\end{array}$} & Respecting the team rules and norms \\
\hline & & $\begin{array}{l}\text { Identifying with and understanding another's } \\
\text { situation, feelings, and motives. }\end{array}$ \\
\hline & & $\begin{array}{l}\text { Listening to other contributions (ideas, opinions, } \\
\text { advice, constructive criticism, etc.) and expressing } \\
\text { one's own with respect. }\end{array}$ \\
\hline & & $\begin{array}{l}\text { Having knowledge and confidence in personal } \\
\text { potential to execute tasks and communicate them. }\end{array}$ \\
\hline & & $\begin{array}{l}\text { Recognizing the strengths of team members and } \\
\text { giving feedback }\end{array}$ \\
\hline \multirow{4}{*}{$\begin{array}{l}\text { COMMUNICATION } \\
\text { Having knowledge for } \\
\text { communicating in different contexts } \\
\text { (personal, social and labour) and } \\
\text { through different means (spoken } \\
\text { and written) }\end{array}$} & \multirow{4}{*}{$\begin{array}{l}\text { It is an essential tool for functioning in } \\
\text { society and the workplace and } \\
\text { participating in a dialogue with other } \\
\text { employees and with employers, } \\
\text { respecting different values, beliefs and } \\
\text { cultures. }\end{array}$} & $\begin{array}{l}\text { Understanding (reading and interpreting) every type } \\
\text { of oral and written message }\end{array}$ \\
\hline & & $\begin{array}{l}\text { Expressing one's self (written and orally) clearly and } \\
\text { correctly }\end{array}$ \\
\hline & & $\begin{array}{l}\text { Adapting non-verbal language to every situation } \\
\text { (gestures, tone of voice and face expression) }\end{array}$ \\
\hline & & Listening attentively \\
\hline \multirow{3}{*}{$\begin{array}{l}\text { PERSEVERANCE } \\
\text { Making a sustainable effort to } \\
\text { complete personal proposals or } \\
\text { tasks, despite difficulties. }\end{array}$} & \multirow[t]{3}{*}{$\begin{array}{l}\text { Required for work, for persisting in the } \\
\text { labour market despite adversity. }\end{array}$} & $\begin{array}{l}\text { Being constant in executing the planned tasks and } \\
\text { actions }\end{array}$ \\
\hline & & $\begin{array}{l}\text { Persisting, despite adverse conditions, to achieve } \\
\text { personal goals }\end{array}$ \\
\hline & & $\begin{array}{l}\text { Completing all tasks and activities, despite not being } \\
\text { motivated. }\end{array}$ \\
\hline \multirow{4}{*}{$\begin{array}{l}\text { FLEXIBILITY } \\
\text { Adapting personal behaviour, ideas } \\
\text { and emotions when required }\end{array}$} & \multirow{4}{*}{$\begin{array}{l}\text { In the labour market, it becomes } \\
\text { important, especially for maintaining } \\
\text { employment and gaining promotion. It } \\
\text { is needed to deal with different labour } \\
\text { situations and contexts. It is also } \\
\text { necessary to adapt to constant work }\end{array}$} & Accepting changes with willingness \\
\hline & & Being open to new ideas, orientations and practices \\
\hline & & Adapting personal behaviour to different contexts \\
\hline & & $\begin{array}{l}\text { Changing ideas when evidence shows that it is } \\
\text { wrong }\end{array}$ \\
\hline
\end{tabular}




\begin{tabular}{clll}
\hline & changes. \\
\hline RESPONSIBILITY AND CO- & Are required to understand unwritten & Carrying on assigned tasks. \\
RESPONSIBILITY & social and work norms and moral & Complying with agreed deadlines \\
Accepting personal obligations and & codes. Implies identifying and & Being involved with the tasks agreed on. \\
those shared with others, and being & assuming the consequences of & Accepting the consequences of personal actions \\
\cline { 2 - 3 } & personal actions in the labour context. & & Being punctual \\
\hline
\end{tabular}

As we can see, certain competence elements are needed not only in the labour market but also in life. All of them allow exercising control on young people in residential care with respect to their everyday life and working transitions. For this reason, the employability competences that we present are considered basic and transversal, because they have multiple areas of usefulness and can be developed and maintained in any labour context.

\section{Educational implications and proposals: how can we develop employability competence for young people in residential care?}

The difficult employment situation of young people in residential care is not inevitable. The essence of employability competence is preparation for employment. Teaching and learning these competences is consistent with the emerging labour-market demands regarding relationships among employment outcomes and the construction of employability.

Competence-employability development for young people in residential care could construct experience and social capital, because they include not only individuals' opinions but also thoughts, feelings, actions and social relations. It is important to take into consideration relevant aspects of employability competences that can be taught.

A competence can itself be learned within a favourable learning environment (DeseCo, 2003). Most of these employability competences are developed in a family context in the first years of life (Sheffield et al. 2007.) Most psychologists agree that the family context has a major impact on children and adolescents' social and emotional development (Eisenberg and Valiente, 2004; Power, 2004). In this case, residential centres have the same responsibility as natural parents in assisting young people to search for, attain and maintain a job. Educational intervention has to be focused on making young people everyday life as similar as the family context by providing them the skills and knowledge necessary for attaining active labour insertion and for living independently. 
Research shows that leaving residential care without a solid base of functional and basic employability competence could have a negative impact on future career outcomes (Mendes, 2009). Residential staff must take special steps to ensure that they teach all the required employability competences by providing a solid preparation at a very early age and until young people leave the care system.

Educational employability interventions have a preventive value in preparing young people not only for active labour insertion but also through involving their comprehensive development. A positive strategy could be integrating employability competences into individual development plans, identifying current and desired competence levels and the everyday-life situations that will be taught in every case. This practice could provide evaluation indicators of employability development that ensure successful care-leaving transitions for youngsters in care and could also represent an indicator for measuring the effectiveness of institutional employability (Harvey, 2001).

It would be also recommendable that employability competences were directly taught and reinforced in schools, since young people develop part of their life within the school context. These competences should be worked on together with other academic skills that they have to be covered in school. Reliable links must be established between schooling and residential-care intervention in order to develop open communications systems that better contribute to the holistic development of young people in residential care.

Educating employability competence could allow young people in residential care to improve life chances and career outcomes. In the future, it will be interesting to trial the IARS Framework Employability Competence with young people in residential care. Even thought the IARS model has emerged from a relatively small number of discussions between a relatively small numbers of experts, it has not yet been tested in practise. It also would be interesting to validate it across countries and cultures and to discuss this with experts, employers, employees, and policy analysts to produce a policy-relevant framework of employability competence for young people in residential care.

Based on the IARS framework, another future proposal would be to develop and validate an instrument to identify what employability competences and components must be maintained and developed within children's homes. Complementarily, it will be important to design an educational programme to make employability competence available for developing strategies directed towards active labour insertion, thereby strengthening youngsters' potential and providing them with much-needed support. 


\section{Acknowledgements}

This study was financed by the Ministry of Education of Spain (EDU2010-16134). We gratefully acknowledge the collaboration of various specialists and academics in the validation process of the IARS framework.

\section{Reference}

Attar-Schwartz, S. 2008. 'Emotional, behavioral and social problems among Israeli children in residential care: A multi-level analysis'. Children and Youth Services Review, 30(2): 229248.

Australian Chamber of Commerce and Industry y Business Council of Australia. 2002. Employability skills for the future, Australia: Department of Education, Science and Training.

Australian Government. 2006. Employability Skills. From Framework to Practise. An introductory Guide for Trainers and assessors, Australia: Department of Education, Science and Training.

Avery, R. J. and Freundlich, M. 2009. 'You're all grown up now: Termination of foster care support at age 18'. Journal of Adolescence, 32(2): 247-257.

Berridge, D. 2007. 'Theory and explanation in child welfare: education and looked-after children', Child and Family Social Work, 12 (1): 1-10.

Cashmore, J. and Paxman, M. 2007. Longitudinal Study of Wards Leaving Care:Four to five years on, Sydney: Social Policy Research Centre.

Cashmore, J., Paxman, M. and Townsend, M. 2007. 'The educational outcomes of young people 4-5 years after leaving care'. Adoption \& Fostering, 31(1): 50-61.

Centre for Developing and Evaluating Lifelong Learning [CDELL]. 2007. The Teaching, Learning and Assessment of Generic Employability Skills, DCELL: University of Nottingham, and the South West Skills and Learning Intelligence Module, University of Exeter http://www.excellencegateway.org.uk/VLSP29/files/app3.pdf

Courtney, M. E., Dworsky, A., Ruth, G., Keller, T., Havlicek, J. and Bost, N. 2005. Midwest evaluation of the adult functioning of former foster youth: Outcomes at age 19, Chicago: Chapin Hall Center for Children at the University of Chicago.

Courtney, M. and Dworsky, A. 2006. 'Early outcomes for young adults transitioning from outof-home care in the USA'. Child and Family Social Work, 11: 209-219.

Crawford, M. and Tilbury, C. 2007. 'Child protection workers' perspectives on the school-towork transition for young people in care'. Australian Social Work, 60(3): 308-320.

Davidson, G., Devaney, J. and Spratt, T. 2011. 'The Impact of Adversity in Childhood on Outcomes in Adulthood'. Journal of Social Work, 10(4): 369-390.

Del Valle, J.F., Álvarez-Baz, E. and Fernanz, A. 1999 Y después...¿qué?. Un estudio de seguimiento de casos que fueron acogidos en residencias de protección de menores en el Principado de Asturias, Oviedo: Servicio de Publicaciones del Principado de Asturias.

Descy, P. and Tessaring, M. 2002. Formar y aprender para la competencia profesional: Segundo informe sobre formación profesional en Europa: Resumen ejecutivo (CEDEFOP Referentes Series, 12), Luxemburgo: Oficina de Publicaciones Oficiales de las Comunidades Europeas. 
Dixon, J. 2006. Pathways to work experience: Helping care leavers into employment, York: University of York.

Dixon, J. 2007. 'Obstacles to participation in education, employment and training for young people leaving care'. Social Work \& Social Sciences Review, 13(2): 18-34.

Down, C. 2000. Key competences in Training Packages, Australia: National Center for Vocational Education and Research (NCVER).

Dutton, R. 2006. Bridges and barriers: A review of Dorset's LPSA 8. Improving the life chances of care leavers, Dorset: Dorset County Council.

Eisenberg N, Valiente C. 2004. 'Elaborations on a theme: Beyond main effects in relations of parenting to children's coping and regulation.' Parenting: Science and Practice, 4:319-323.

Farruggia, S. P., Greenberger, E., Chen, C. S. and Heckhausen, J. 2006. 'Perceived social environment and adolescents well-being and adjustment: Comparing a foster care sample with a matched sample'. Journal of Youth and Adolescence, 35(3): 349-358.

Forrier, A. and Sels, L. 2003. The concept employability: a complex mosaic. International Journal of Human Resource Management, 3(2): 125-124.

Foster Care Work Group. 2004. Connected by 25: A plan for investing in successful futures for foster youth, Washington, DC: Finance Project.

Fugate, M., Kinicki, A. J. and Ashforth, B. E. 2004. Employability: A psycho-social construct, its dimensions, and applications. Journal of Vocational Behavior, 65(1): 14-38.

Geenen, S. and Powers, L. 2007. 'Tomorrow is another problem: The experiences of youth in foster care during their transition into adulthood'. Children and Youth Services Review, 29: $1085-1101$.

Gilligan, R. 2007. 'Adversity, resilience and the educational progress of young people in public care'. Emotional and Behavioural Difficulties, 12 (2): 135 - 145.

Harvey, L. 2001. 'Defining and measuring employability'. Quality in Higher Education, 7: 97109.

Hillage, J. and Pollard, E. 1998. 'Employability: developing a framework for policy analysis'. Research Brief, 85. ERIC ISBN 085522889X

International Labour Office (ILO). 2010. Increasing the employability of disadvantaged youth: responding to the impact of the financial and economic crisis, Guidance Note, International Labour Organization.

Johns, G. 2006. 'The essential impact of context on organizational behavior'. Academy of Management Review, 31(2): 386-408.

Kearns, P. 2001. Generic Skills for the new economy-review of research, Australia: National Centre for Vocational Education and Research (NCVER)

Kirschner, P.A. and Thijssen, J. (2005). 'Competency development and employability'. Lifelong Learning in Europe, 2: 70-75.

Le Boterf, G. 2001. Ingeniería de las competencias, Barcelona: Gestión 2000.

Lindsay, C., McQuaid, R. and Dutton, M. 2007. 'New Approaches to Employability in the UK: Combining Human Capital Development and Work First Strategies? '. Journal of Social Policy, 36(4): 539-560.

López, M., Santos, I. Bravo, A. and Del Valle, J.F. in press. 'El proceso de transición a la vida adulta de jóvenes acogidos en el sistema de protección'. Anales de Psicología. 
Massinga, R. and Pecora, P.J. 2004. 'Providing better opportunities for older children in the child welfare system'. The Future of Children, 14: 151-173

McArdle, S., Waters, L., Briscoe, J. and Hall, D.T. 2007. Employability during unemployment: adaptability, career identity and human and social capital. Journal of Vocational Behavior, 71: 247-264.

McQuaid, R. W. 2006. Job search success and employability in local labor markets. Annals of Regional Science, 40: 407-421.

Mendes, Ph. 2009. Young people transitioning from state out-of-home care. Jumping hoops to access employment. Australian Institute of Family Studies, 83: 32-38.

Mertens, L. 1998. Competencia laboral: Sistemas, surgimiento y modelos, Montevideo: CINTERFOR/OIT.

Naccarato,T., Brophy, M.and Courtney, M.E. 2010. 'Employment outcomes of foster youth: The results from the Midwest Evaluation of the Adult Functioning of Foster Youth'. Children and Youth Services Review, 32: 551-559

Pecora, P., Kessler, R., O’Brien, K., Roller, C., Williams, J. and Hiripi, E. 2006. 'Educational and employment outcomes of adults formerly placed in foster care: Results from the Northwest Foster Care Alumni Study'. Children and Youth Services Review, 28: 14591481.

Paul-Ward, A. 2009. 'Social and occupational justice barriers in the transition from foster care to independent adulthood'. American Journal of Occupational Therapy, 58: 64-72.

Power TG. 2004. 'Stress and coping in childhood: The parents' role.' Parenting: Science and Practice, 4:271-317.

Pugh, C. 2008. Step in the right direction: Rhondda Cynon Taf Traineeship Programme, Tonypandy, Wales: Rhondda Cynon Taf Borough.

Sheffield Morris, A., Silk, J.S., Steinberg, L., Myers S.S., Robinson, L.A. 2007. 'The Role of the Family Context in the Development of Emotion Regulation'. Social Development, 16(2): 361-388.

Stein, M. 2004. What works for young people leaving care?, Ilford: Barnardo's.

Stein, M. 2006. 'Research review: young people leaving care'. Child and Family Social Work, 11(3): 273-279

Stein, M. and Munro, E. (Eds.). 2008. Young people's transitions from care to adulthood: International research and practice, London: Jessica Kingsley.

Tilbury, C., Buys, N. and Creed, P. 2009. 'Perspectives of young people in care about their school-to-work transition'. Australian Social Work, 62: 476-490.

Thijssen, J. G. L. 1998. Employability and lifelong learning, Leuven, Belgium: Katholieke Universiteit Leuven.

Thijssen, J., Van der Heijden, B. and Rocco, T. 2008. 'Toward the employability_Link Model: Current Employment Transition to future Employment Perspectives'. Human Resource Development Review, 7(2): 165-183.

UK Commission for Employment and Skills. 2009. The Employability Challenge, UK: Commission for Employment and Skills.

UK Commission for Employment and Skills. 2010. Employability Skills: a Research and Policy Briefing, Briefing Paper Series, UK: Commission for Employment and Skills.

U.S. Department of Labor, Secretary's Commission on Achieving Necessary Skills. 1992. Learning a living: a blueprint for high performance, Washington, DC: Government Printing Office. 
Van Dam, K. 2004. 'Antecedents and consequences of employability orientation'. European Journal of Work and Organizational Psychology, 13: 29-51.

Van der Heijde, C. M. y Van der Heijden, B. I. J. M. 2006. 'A competence-based and multidimensional operationalization and measurement of employability'. Human Resource Management, 45(3): 449-476.

Van der Heijden, B.I.J.M. 2002. 'Prerequisites to guarantee life-long employability'. Personnel Review, 31(1): 44-61.

Van der Heijden, B. I. J. M., and Thijssen, J. G. L. 2003. 'Editorial: HRD and employability'. International Journal of Human Resources Development and Management, 3(2), 99-101.

Wade, J. and Dixon. J. 2006. Making a home, finding a job: Investigating early housing and employment outcomes for young people leaving care. Child and Family Social Work, 11: 199-208.

Yorke, M. and Knight, P.T. 2006. Embedding Employability into the Curriculum, Enhancing Student Employability Co-ordination Team. (ESECT), York: The Higher Education Academy.

Authors own. 2009a. "Analysis of factors involved in the social inclusion process of young people fostered in residential care institutions'. Children and Youth Services Review, 31: $12,1251-1257$.

Authors own. 2009b. 'Characteristics and sociolabour insertion of young people after residential foster'. International Journal of Child and Family Welfare, 12(1): 22-34. 